\title{
The Impact of Computer on the Deviant Behaviors Exhibition of Teenagers : A Case Study of Albania
}

\author{
Eljana Brahja, PhD Candidate \\ Faculty of Social Sciences, Tirana University, Albania
}

doi: 10.19044/esj.2017.v13n26p84 URL:http://dx.doi.org/10.19044/esj.2017.v13n26p84

\begin{abstract}
Technology is placing teenagers in front of diverse choices that the virtual world enables. The purpose of this study is to explain how technology affects relationships that teenagers have with other individuals in the real world. The study's research question is: Does the use of computers affect the exhibition of deviant behaviors among teenagers? The research method used for the findings of this study is the quantitative method. Data was collected using a questionnaire. The population of the study was 1,680 teenagers from Sander Prosi and Myslym Keta high schools located in Tirana, Albania. The sample selected according to the defined criteria for completing the questionnaires is 453 students from the $10^{\text {th }}, 11^{\text {th }}$ and $12^{\text {th }}$ grade. Based on the Positive Paradigm, the quantitative research method will serve to recognize the reality. Research data is processed through the SPSS statistical method and the result with the Cronbach alpha validation coefficient, $\alpha=$ 0.852. Based on the Interactional Theory (Thornberry, 2015), it is aimed to shed light on the behavioral patterns exhibited by teenagers who are computer users. From the research findings, students who used computer to play, and not for scientific research, were more involved in deviant behavior. They were predisposed to conflict with friends, dim relationships with people surrounding them in the real world, dropping out of school, etc. To avoid such a situation, it is recommended to strengthen the cooperation in the real world amongst parents, students, and teachers.
\end{abstract}

Keywords: Technology, virtual world, real world, deviance, romantic individualism

\section{Introduction}

Computers, mobiles, and tablets are technological tools that can be used by everyone. They can serve for research purposes, to connect with others through the use of social networks, to play, to get information about the latest news, etc. The time devoted to these tools is not small; the same is 
the impact they have on us. However, their use is necessary to engage in what many scholars call "globalization". Some studies indicate that the phenomenon of globalization is affecting all countries, developed and developing ones. Globalization has affected Albania as well. The issue of globalization continues to be debated, assessed and re-evaluated, anathematized or glorified, ignored, or put on a pedestal (Civici, 2009, p. 13). As a result, this demonstrates how complex and whole-inclusive the phenomenon is. This is along with the technological innovations it has brought. Often, the use of technological tools contradicts traditional ways of organizing life and the time spent on activities needed by people such as information, collaboration, entertainment, etc.

Not all countries absorb globalization in the same way. It is clearly evident that the study of how people of different societies engage in globalization and how they face the alternatives offered through a world as real and as virtual, as the one created by technology, is of particular importance. The real world is already becoming a world registered and reinforced through the Internet. Our vital experiences are shared very quickly and somehow we are guarded by others in what we do and with what we deal with (Bonk, 2009, p.5). As Manuel Castell points out, in terms of spreading and using new technologies, the whole world is involved in a kind of technological globalization. The Internet nowadays can be considered as the "virus" that has conquered the world, starting from children to the elderly (Shtepani, 2007, p. 290). Castell describes contemporary society as a global information economy, where the global structure of the global system is based on logic of flow, connectivity, networks, and joints. The scholar, Curtis J. Bonk, sees technology as an element that has opened up the education process all over the world to the point where everyone can learn something from someone else and at all times.

The use of technology is a new way of learning that helps both students and teachers who are also the most numerous computer users (Bonk, 2009). Other scientific research has demonstrated that innovations in the field of technology such as computers, tablets, or mobiles have brought social changes, and has also influenced the emergence of forms of deviance. Some individuals use technology as a tool to deviate from traditional cultural norms (Boundless, 2017). Except when deviances bring positive changes into the society, other deviances should be treated with particular care.

Based on the Positive Paradigm, we recognize that using a computer for study reasons brings development to the society by including it in the global flow. According to this paradigm, we face the same reality every day. Some people use technology while others misuse it. The use of the computer for a very long time can cause negative consequences. Missing of parental control and navigating on inappropriate websites can turn the computer into 
an inexhaustible source of learning deviant behavior. There is a growing need to study the consequences of using technology and the impact it has on high school teenagers. If in the reality it surrounds something that does not work properly, we should try to study and understand the real causes of deviant behavior in teenagers.

The importance of this research lies in explaining how the use of technology affects the relationships that teenagers have with other individuals in the real world. Some studies point to the consequences of using the computer, but they do not explain how it can be turned into a tool that fosters and drives the deviant behavior of the individual to the point of dropping out of school, having conflicts with peer groups, and even engaging in romantic relationships between the user and the computer. The objectives of this research are:

- Evaluating the degree of high school student involvement in computer use.

- $\quad$ Determining the purpose the computer is most commonly used by high school students.

- $\quad$ Assessing the degree of conflicting relationships between computer users and other real-world individuals.

- $\quad$ Identifying school drop-out cases due to online gaming.

- $\quad$ Determining the impact of the computer on forms of social deviation and control.

- $\quad$ Recommendations and suggestions for improving the reality.

It is important for a society to highlight the problem, the extent to which it has spread, and then make relevant recommendations to limit the consequences that may arise. In this period of globalization, teenagers face both the real and the virtual world. It is imperative to understand exactly how to put the virtual world to the service of the real one and not have it as an obstacle to the development of healthy relationships among teenagers or for regular school attendance. We are the ones who should not allow the use of the computer be turned into a source of conflict among teenagers. The emphasis is on teenagers and the way they perceive the use of computers. This is because they are at the stage of adolescent development and as it is also determined by scholars, adolescence is a transition period from dependence into independence (Pettijohn, 1996, p. 95). We have to pay special attention to the ways of orienting a teenager's behavior. These orientations have to be derived from the family, school, and community surrounding them. 


\section{Literature Review}

\section{The Format of Deviance under the Influence of Technology}

According to Boundless, deviations give to the society boundaries to determine acceptable and unacceptable behavior in the society. He sees technology as a key mechanism for social regulation and development. Innovations in the field of technology help the society to better absorb the globalization process. On the other hand, he emphasizes that technology influences the emergence of deviant behaviors. People affected by technology can be involved even in crimes (Boundless, 2017). Young people use the computer as a way to express themselves in the most extreme form. Brand preferred to counteract cultural power by building a society with something that could well be called Byronic - a traditional romantic sense of pleasure that was mixed with rebellion, in the sense of expression and individual creativity, but that in some cases it could affect the other members of the society (Streeter, 2009, p.45). According to Brand, people need to express themselves, be spontaneous, creative, and they can do this well using the computer.

Another study shows that there is an agreement between teenagers and their parents about whether the internet can be a useful tool for the school (Hitlin \& Rainie, 2005). Study findings demonstrate that this agreement has in some cases been raised on teenagers who deceitfully played online more than studied. The same viewpoint for using technology has also the writer (Bly, 1984) according to whom we are lying to ourselves thinking that using a computer is bringing us revival. Today's teenagers are very poor in communication and all the time spent online is reflected in school or universities where their tests don't show good performances (Tapscott, 2009).

Interactional Theory, which is a combination of Social Control Theory and Social Learning Theory, formulated by Terrence P. Thornberry in 1987, suggests that weak social ties and lessons encourage deviant behavior. Based on this theory, teenagers who have poor relationships with family members, or with the group of friends surrounding them in the real world, are more likely to exhibit different forms of deviance.

The researcher, Tapscott, has made a list of computer usage dark sides. Many of them can be seen from the perspective of deviant behaviors that are not in conformity with the rules and norms of the society. According to him:

- $\quad$ Today's teenagers are turning from the internet generation to the mute generation.

They are losing social skills by having no time to deal with outdoor sports activities. 
- They are no longer ashamed; many of today's teenagers post provocative pictures online.

- $\quad$ Teenagers have become insecure to pave the way for their future.

- They steal. They download music, do plagiarism, and share everything that appears on the computer network, violating human rights, and have no respect for their creator.

- $\quad$ They bully friends online.

- $\quad$ They become violent, affected by violent online games.

- $\quad$ They have no ethics in their work. To carry out their job duties and they are dependent on navigating the Internet to find shortcuts.

They experience shrinking social value and do not care about the others that surround them in the real world.

All of these will affect the intelligence of human beings and will change the way they think globally (Tapscott, 2009).

\section{Creating Romantic Relationships through the Computer and with the Computer}

Current studies show that computer users can create emotional relationships with other people online, but at the same time with the computer itself. During adolescence, relationships with peers and mainly romantic relationships occupy a special place in teenagers (Lenhart, Anderson, \& Smith, 2015). Key findings from Lenhart, Anderson and Smith (2015) demonstrate that the role technology plays in teenagers' romantic relationships is critical. The digital sphere is an important part of globalization and online space plays a major role on how teenagers flirt, mock, and communicate conflictingly with one another. Computer is the tool that unites teenagers in a romantic relationship, but can also easily disconnect them.

According to the researcher, Tapscott, young people today find it difficult to cope with the reality and the commitments and responsibilities that are needed for it. They are so afraid of commitments that some of them will never get married. Today's youth will stay at home, never being disconnected from the warm relationship they have with the computer (Tapscott, 2009). The same point of view was established by the author, William Damon. According to him, the computer is a digital device which is in direct contact with the feelings of teenagers and can easily organize their world. Entering the site that we like, affects our real life. The emotion that is caused is real, while the energy that drives us to make decisions is a virtual energy. The strong relationship that is created with the computer from almost all of its users leads to what Thomas Streeter describes as "romantic individualism" which seems to be greatly affecting the romantic relationship between people in the real world. Romance sensation needs to be created 
between people and not between computer users and the vehicle itself (Streeter, 2009, p. 46-48).

\section{Computer Influence in Relationships with Real-World Individuals}

Nowadays the generations have changed immensely. They interact with technology and have changed the ways of playing, learning, communicating, and many others. According to the researchers, individuals aged 11 to 30 are the ones who use the computers more. Their reasons are different; to chat with friends, to download music, to upload videos, to watch a movie on screen, etc. They are the first generation that have grown digitally, and are part of a global cultural phenomenon. Otherwise, they may be called "Net Generation" (Tapscott, 2009). However, the use of technology has attracted almost every age, from the youngest to the oldest, by changing the ways of their relationship. The Net Generation has grown up with information technology. The aptitudes attitude, expectation, and learning style of Net Gen students reflect the environment in which they were raised. This environment is different from what has existed before (Oblinger \& Oblinger, 2005).

Kids see cartoons on the internet, teenagers chat with their friends, older people communicate via skype with relatives, etc. Divorce from the real world, has unconsciously created a gap in relationships with people around us, making us create communities that are very different from what our parents had before. There is not so much communication with parents, we do not play as before with sisters or brothers, we do not walk with our friends as before, we deal very little with sports activities, etc., and these are the life characteristics gained from the impact of the computer on each of us. Conflicts between teenagers are present in the real world. Just as in the real world, they are also present in the virtual world. Studies show that computersent messages serve as a good way to break the relationship that teenagers have created with peers in the real world. A survey conducted by Lenhart, Anderson and Smith shows that $31 \%$ of respondents have ended up in conflicting relationships via online messaging (Lenhart, Anderson, \& Smith, 2015).

Other studies show that the computer plays an important role on how teenagers meet and interact with their friends. As the network of relationships created in the virtual world is expanding and getting stronger, the network of relationships between teenagers and family members or their peers in the real world narrows and fades (Lenhart, 2015). The same conclusion was also reached by the researcher, Tushi. Teenagers should interact more with the group by placing an equilibrium between the society and the human being, the social group and the individual as a "real social object" and not a virtual one (Tushi, 2009, p.323-330). According to him, 
today's teenagers have reduced their direct relationship with others by becoming less and less involved in the real world social life.

\section{Research Method and Research Design}

Quantitative research method is the method used for carrying out this study. This method has been selected because it allows us to collect data from a wider sample within a short time (Bailey, 1982). Also, in order to avoid the shyness that the teenagers may have in completing the questionnaires, the latest was anonymous. Questionnaires were completed by students from "Sander Prosi" and "Myslym Keta" high schools. These schools are located in sub-urban areas. These two schools are also the population of this research. During the academic year 2016-2017, 1,680 students studied in these schools. The pupils' community is heterogeneous because the neighborhoods of Sauk and Kombinat (respective neighborhoods where these schools are located) were populated mainly after the 1990s by migratory movements. 'Sander Prosi' school is located in the East referring to the center of Tirana, and the "Myslym Keta" school in the West. Being in such geographic locations, 'Sander Prosi' school has gathered students who have migrated from the northern part of Albania and the school "Myslym Keta" has mainly students coming from Southern Albania. This heterogeneous community of students will help us to collect various and diverse mindsets from almost all the cities of Albania.

In the study of these two schools, 1,680 students make up the population of this study. The purposive sampling technique was used to select 453 students who are aged 16 to 18 years and who are in grades 10 to 12.

By assessing the needs of teenagers using the computer, the relevant recommendations for reducing long hours in front of the computer can be offered, so that teenagers are more present in the real world than the virtual one. By relying on these research findings, the relevant recommendations will be provided in order to improve the reality.

\section{Reliability and Validity of the Instruments}

The instrument used to collect the data is the questionnaire. Closedended questionnaires were used to keep the teenagers focused on the issue to be studied and it also help to avoid the student's emotional colorings. The time needed to complete the questionnaires was 35-40 minutes. Completion of the questionnaires within this time enabled students to focus on completing it, avoiding the delays that could be caused by the ringing of the bell to notify the end of the lesson. To identify the uncertainties that could arise in completing the questionnaires, the latest was first tested in three pilot classes. These classes are a 10th grade class from the school "Myslym Keta" 
and two classes (grade 11 and 12) from the "Sander Prosi". Each student's suggestion served to improve the survey. In the formulation of this survey, a simple and comprehensible language was used considering the age at which it was addressed. Likewise, terms that may lead to potential prejudices were avoided.

The result of the pilot study indicated that the reliability score for all items is Cronbach alpha $(\alpha)=0$. 852. This alpha value indicates that the survey questions were logically linked to each other and in a proper way showing a high level of credibility.

In order to determine the validity of the survey, experts on the social and economic field from the Faculty of Social Sciences and the Faculty of Economics in Tirana were engaged.

\section{Data Analysis And Discussions}

The students of the two schools that make up the sample of this research belong to a heterogeneous cultural community. They carry with them the rules and cultural norms of the cities from which they come from. From the findings of this study, it turned out that $98 \%$ of respondents $(226$ boys and 218 girls) are aware of using technology such as computers, cell phones, or tablets. Only $2 \%$ of them do not know how to use technology, out of which 6 are girls and 3 are boys. Such values tell us that the novelties of technology are present and usable in Albania as well as in many developing countries of the world. Some textbooks have been digitized and each school has its own IT cabinet. This has helped Albanian teenagers absorb alternatives offered in the technological field.

When teenagers were asked the question 'What do you use the technology mostly for?' 45\% of the respondents (167 boys and 32 girls) answered that they mostly use it for playing games. From the respondents' feedback, boys are more passionate about playing online and girls are more passionate about studying and chatting.

Graph 1. What do you use the technology mostly for?

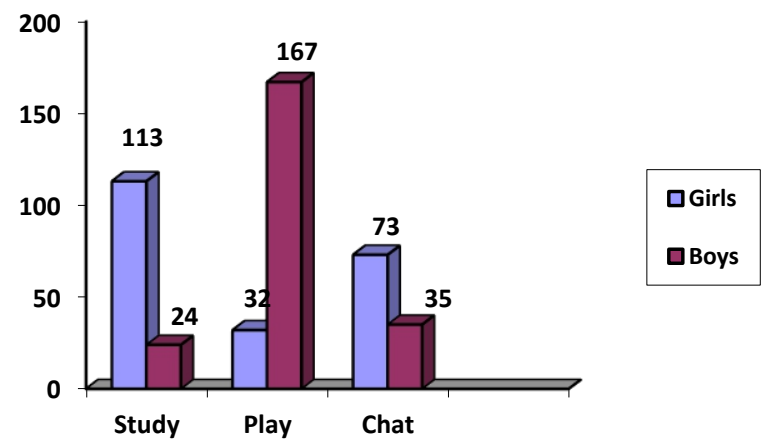


The number of teenagers who play and chat online is higher than the number of teenagers who use the computer and internet to get the information needed for the study. This data shows that we are dealing with a misuse of technological tools. This situation requires immediate intervention in social policies that introduce teenagers to technological innovations and provide the appropriate orientations to have a better use of technology.

To understand how the use of the computer affects the relationships that teenagers create with the device (computer) and with the individuals that surround them in the real world, they are asked with whom they would like to spend more time: with their family members, their peers or with the computer. The questionnaire data showed that $40 \%$, or 182 teenagers, preferred to spend more time with the computer because through it, they could stay online with their friends and also with others they didn't know directly. Referring to data retrieved from the processing of questionnaires, $28 \%$ prefer to spend more time with parents and $32 \%$ with peers.

Graph 2. With whom would you like to spend more time?
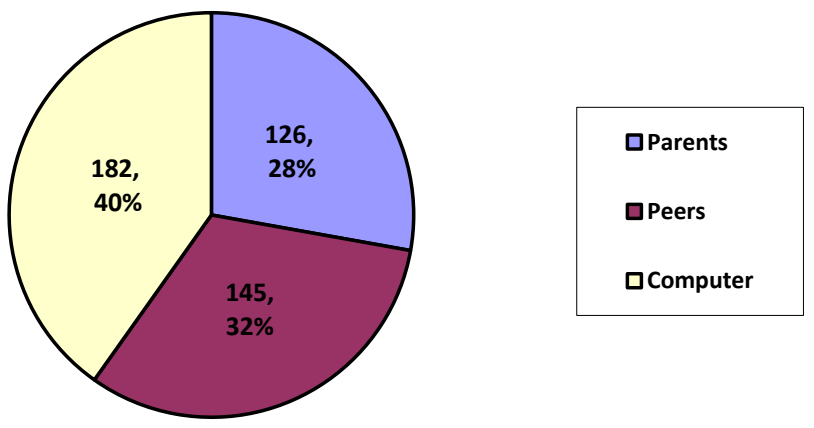

Based on Interactional Theory of Terrence P. Thornbery, by comparing the number of teenagers who wanted to spend time with their parents, with the number of teenagers who wanted to spend time with the computer, we could say that separation from parents and also from direct relationships with the group of peers, can lead to weak social learning that encourage deviant behavior. To describe the impact of the computer usage on deviant behaviors exhibitions in teenagers, they were asked on which of the behaviors they exhibit most frequently while staying online. The results of this research revealed that deviant behaviors were present among them. Out of the 444 students who were computer users, $41 \%$ of teenagers claim that they often commit 'theft' during their online time, 33\% conflict with their peers, $23 \%$ deal more with plagiarism, and only $3 \%$ think they do not show any of these behaviors. 
Graph 3. Which of the behaviors do you exhibit most frequently while staying online?

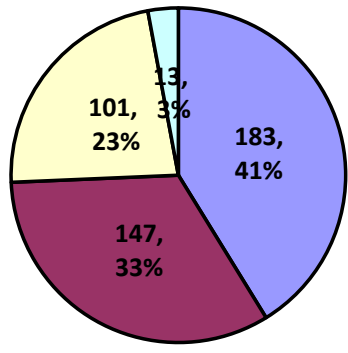

口Stealing
$\square$ Conflictual
$\square$ Plagiarism
$\begin{aligned} & \text { ane of the } \\ & \text { above }\end{aligned}$

Also, the findings of this study demonstrate that the environment where teenagers use the computer more often is the school. $43 \%$ of respondents use the computer during school time, $19 \%$ use it during their stay at home, and $38 \%$ use it when they are around in the neighborhood.

\section{Conclusion and Recommendations}

Although the use of technology is an important element for globalization, it carries with it a number of problems for the society. However, these are problems that are caused not by use but by misuse of computers, cell phones, or tablets.

According to Tapscott, today's teenagers are losing social skills to build direct relationships with those surrounding them and have no time to deal with outdoor sports activities. They are not ashamed to steal, to download music, to plagiarize, and to violate human rights (Tapscott, 2009). The data in this study seems to support this. $41 \%$ of respondents claim that online theft is the behavior they display most often during their navigation on the Internet. This behavior requires immediate intervention in order to limit and minimize the consequences it may cause in the future.

This study shows that globalization is creating a virtual world that is weakening direct relationships between teenagers in the real world and is encouraging behaviors that contradicts social rule. As an immediate need arises, there is the need to strengthen the position of parents in the control of teenagers. By involving teenagers in decision-making or family conversation, spending time with parents can become even more attractive to them than playing an online game.

The findings of the study are explained based on the Interactional Theory formulated by Terrence P. Thornberry, which is a combination of Social Control Theory and Social Learning Theory. According to the Social Control Theory, parental control when teenagers use the computer is not possible because they use it more during school hours. Even when teenagers use the computer at home, parental control is not enough because in most cases teenagers are hidden under the justification that they are using it to 
search for information they need at school. Since some of the burden of controlling the use of the computer falls on the teacher, it is recommended that they should be trained on strategies that would help to stop the addiction of teenagers to the computer. Teachers can educate students on using the computer as an instrument for studying, rather than chatting or playing online games endlessly. Also, correctly enforcing school rules by both teachers and students can stop school dropouts caused by online games.

In addition, based on the Theory of Social Learning, we can explain how globalization and the environment surrounding teenagers influence their learning and behavior. People learn from each other and reflect the learned approach. In this open world, as the researcher, Bonk, calls it, it is important to design global social policies that educate teenagers on ways to use technology without being enslaved by it. Teenagers should not only learn from the behavior of others, but should also recognize the consequences such behavior can bring.

The combination of the elements of these two theories leads us to the Interactional Theory, according to which inadequate parental control and poor social teaching encourage teenagers to exhibit deviant behavior. In light of these findings, this document enriches the discussions on whether the computer can be considered an instrument that educates or an instrument that destroys teenagers aged 16 to 18, encouraging the display of behaviors that are inconsistent with the rules and norms of society.

\section{References:}

1. Civici Adrian (2009). Globalizimi...ante portas,Shtepia Botuese UET Press, Tirane: 13 - 20.

2. Bailey, K.D. ( $2^{\text {nd } E d .) ~(1982) . ~ M e t h o d s ~ o f ~ s o c i a l ~ r e s e a r c h . ~ L o n d o n: ~}$ Collier Macmillan Publishers.

3. Bly, W. Robert (1984). The puffin dictionary of computet words. Puffin/Penguin books.

4. Bonk, J. Curtis (2009). The World is Open: How web technology is revolutionizing education, published by Jossey-Bass.

5. Boundless (2017). Deviance and Technology. Retrived from https://www.boundless.com/sociology/textbooks/boundlesssociology-textbook/deviance-social-control-and-crime-7/deviance59/deviance-and-technology-365-1323/

6. Hitlin, P., \& Rainie, L. (2005). Teens, Technology and School. Retrieved from http:/www.pewtrusts.org/en/research-andanalysis/reports/2005/08/04/teens-technology-and-school

7. Lenhart, A., Anderson, M. \& Smith, A. (2015). Teens, Technology and Romantic Relationships. Retrieved from 
http://www.pewinternet.org/2015/10/01/teens-technology-andromantic-relationships/

8. Lenhart Amanda (2015). Teens, Technology and Friendships. Retrieved from http://www.pewinternet.org/2015/08/06/teenstechnology-and-friendships/

9. Tapscott Don (2009). Grown up digital: How the Net generation is changing your world, McGraw- Hill.

10. Oblinger, G. Diana \& Oblinger, L. James (2005). Educating the Net Generation. EDUCAUSE.

11. Thornberry, P. Terrence (2014). Interactional Theory of Delinquency, Springer Science + Business Media New York, 586 603.

12. Streeter Thomas (2009). Net Effect: Romanticism, Capitalism, and the Internet, New York University Press. P.45 - 48.

13. Shtepani Vasilika (2007). Sociologji Urbane, Shtepia Botuese "ORA", Tirane: Kapitulli XIV.5, 290 -291.

14. Pettijohn, F. Terry (1996). Psikologjia: Nje hyrje konçize, Shtepia Botuese "LILO", Tirane. Pp. 95.

15. Tushi Gezim (2009). Sfidat e Qytetërimit. Probleme sociologike te njeriut, shoqerise dhe qyteterimit shqiptar, Shtepia Botuese EMAL. P.323 -351 